\title{
"Israel's" Only Son? The complexity of Benjaminite identity between Judah and Joseph
}

\author{
BENJAMIN D. GIFFONE (LCC INTERNATIONAL UNIVERSITY, \\ STELLENBOSCH UNIVERSITY)
}

\begin{abstract}
Several studies in recent years have sought to articulate the significance of the tribe of Benjamin for historical and literary studies of the Hebrew Bible. This paper suggests that the received text of Genesis 35-50 both reflects and illumines the complexities of Israelite identity in the preexilic, Babylonian, and Persian periods. The fact that Benjamin is the only son born to "Israel" (other sons are born to "Jacob") points to Israel's origins in the land that came to be called "Benjaminite." Between Josephites to the north and Judahites to the south, Benjaminites preserved a unique identity within the polities of Israel, Judah, Babylonian Yehud, and Persian Yehud. In Genesis 35 and 42-45 in particular, the silent character Benjamin finds himself in the middle of a tug-of-war between his brothers, particularly his full-brother Joseph and his half-brother Judah. The conciliatory message of the narrative of Genesis 35-50 for later communities comes into sharper focus when we see the compromise between tribal identities embedded in the text. ${ }^{1}$
\end{abstract}

KEYWORDS: Genesis, Tribe of Benjamin, Joseph Novella, Persian Period, identity formation, narrative

\section{A INTRODUCTION}

Though vigorous debates continue concerning the process by which the books of Genesis to Kings were composed and edited, many scholars have contended that the Pentateuch in its received form is a text that attempts carefully to balance competing sources and perspectives. ${ }^{2}$ Recent reconstructions of the tribal

* Submitted: 10/04/2019; peer-reviewed: 12/09/2019; accepted: 27/09/2019. Benjamin D. Giffone, "Israel's" Only Son? The Complexity of Benjaminite Identity between Judah and Joseph," Old Testament Essays 32 no. 3 (2019): 956 - 972. DOI: https://doi.org/10.17159/2312-3621/2019/v32n3a10.

I am grateful for feedback on earlier versions of this paper presented in the Stellenbosch Graduate Seminar in Old Testament, April 2014, and at the international SBL meeting, Helsinki, August 2018.

2 Gary N. Knoppers and Bernard Levinson, eds., The Pentateuch as Torah: New Models for Understanding Its Promulgation and Acceptance (Winona Lake, IN: Eisenbrauns, 2007). David Glatt-Gilad even argues that the Chronicler modelled his work after the newly-finalized and newly-authoritative Pentateuch; see "Chronicles as Consensus Literature," in What Was Authoritative for Chronicles? (ed. Ehud Ben Zvi and Diana Edelman; Winona Lake, IN: Eisenbrauns, 2011), 69. 
histories of Benjamin, Judah, Manasseh and Ephraim from the period of the Israelite monarchies onward open up new possibilities for interpreting the tribal narratives of the Pentateuch.

In a recent monograph, I have argued that the book of Chronicles is a form of consensus-building literature. ${ }^{3}$ The Chronicler's perspective on Israel's story is pro-Levi and pro-Judah; yet he goes to great lengths to present Benjamin in a positive light as well. This contrasts with the portrayal of Benjamin in the Chronicler's main source, the Deuteronomistic History, which puts on display the varied, messy history between Benjamin and Judah. The Chronicler, recognizing that the floundering second temple in marginalized Jerusalem (within the Persian Empire) needed the support of more successful Benjaminite areas to the north, crafts a narrative to argue that All Israel should worship at Jebus/Jerusalem (on the border between Benjamin and Judah), and that Benjamin and Judah had early and always enjoyed close ties.

In this paper, I suggest that the received text of Genesis 35-50 may be read fruitfully as an attempt to use the character of Benjamin to mediate between the complex "Israelite" identities in the pre-exilic, Babylonian, and Persian periods. Between Josephites to the north and Judahites to the south, Benjaminites preserved a unique identity within the polities of united Israel, Judah, Babylonian Yehud, and Persian Yehud. Benjamin's unique status as the only child born to Jacob after he receives the designation "Israel" reflects the origins of the Israelite monarchy in Benjamin. In Genesis 35 and 42-45 in particular, the silent character Benjamin finds himself in the middle of a tug-of-war between his brothers, particularly his full-brother Joseph and his half-brother Judah. The conciliatory message of the narrative of Genesis 35-50 for later Yehudian communities comes into sharper focus when we see the compromise between tribal identities embedded in the text.

\section{B HISTORY OF THE TRIBE OF BENJAMIN ${ }^{4}$}

Several studies in recent years have sought to articulate the significance of the tribe of Benjamin for historical and literary study of the Hebrew Bible. ${ }^{5}$ Davies

3 Benjamin D. Giffone, 'Sit at My Right Hand': The Chronicler's Portrait of the Tribe of Benjamin in the Social Context of Yehud (LHBOTS 628; New York: Bloomsbury T\&T Clark, 2016).

4 This section largely summarizes material presented in Giffone, Sit at My Right Hand, particularly 85-120, and Giffone, "'Special Forces': A Stereotype of Benjaminite Soldiers in the Deuteronomistic History and Chronicles," SJOT 30.1 (2016): 16-29.

5 A few examples include: Yigal Levin, "Joseph, Judah and the 'Benjamin Conundrum," Z ZAW 116 (2004): 223-41; Joseph Blenkinsopp, "Benjamin Traditions Read in the Early Persian Period," in Judah and the Judeans in the Persian Period, ed. Oded Lipschits and Manfred Oeming (Winona Lake, IN: Eisenbrauns, 2006), 629-45; Philip R. Davies, "The Trouble With Benjamin," in Reflection and Refraction: Studies 
comments, "The tribe and territory of Benjamin is an intriguing phenomenon, and remarkably underplayed in biblical scholarship." ${ }^{6}$ By interpreting limited archaeological data through the texts of the Former Prophets and Ezra, Benjamin becomes surprisingly significant for understanding the histories of Israel and Judah.

Archaeology points to the origins of Israel as a nation under a king in the area that comes to be described in biblical texts as belonging to "Benjamin." The biblical narratives do portray the borders of Benjaminite territory as shifting over time. ${ }^{8}$ The apparent fluidity of the borders of Benjaminite, Northern/Samarian, Judahite, and Philistine territories makes definite, precise statements about the interactions between these groups quite difficult. Certain towns and cities appear to have been continuously settled for long periods of time and are consistently listed as belonging to Benjamin in the Hebrew Bible; these might be called "Benjaminite" with reasonable confidence. The land that became identified with Benjamin seems to have been home to a great number of important cultic sites (במות) through much of Israel's history, including Gibeon, Beth-aven, Bethel, Nob, Mizpah, and—most importantly—Jerusalem. ${ }^{9}$

Moreover, it is highly significant that the biblical text describes the first king of Israel, Saul, as a Benjaminite. ${ }^{10}$ Archaeologists, while hesitating to

in Biblical Historiography in Honour of A. Graeme Auld, ed. Robert Rezetko et al., VTSup 113 (Leiden: Brill, 2007), 93-111; Nadav Na'aman, "Saul, Benjamin and the Emergence of 'Biblical Israel' (Parts 1 \& 2)," ZAW 121 (2009): 211-24, 335-49; Daniel E. Fleming, The Legacy of Israel in Judah's Bible: History, Politics, and the Reinscribing of Tradition (New York: Cambridge University Press, 2012), 144-161; Louis C. Jonker, "Of Jebus, Jerusalem and Benjamin: The Chronicler's Sondergut in 1 Chronicles 21 Against the Background of the Late Persian Era in Yehud," in Chronicling the Chronicler: The Book of Chronicles and Early Second Temple Historiography, ed. Tyler F. Williams and Paul S. Evans (Winona Lake, IN: Eisenbrauns, 2013), 81-102.

$6 \quad$ Philip R. Davies, "The Trouble with Benjamin," 93.

7 Avraham Faust, "Settlement Patterns and State Formation in Southern Samaria and the Archaeology of (a) Saul," in Saul in Story and Tradition (ed. Carl S. Ehrlich and Marsha C. White; FAT 47; Tübingen: Mohr-Siebeck, 2006), 14. Levin, "Joseph, Judah and the 'Benjamin Conundrum,"' 223-241.

8 Faust, "Settlement Patterns," 18-19.

9 Scott M. Langston, Cultic Sites in the Tribe of Benjamin: Benjaminite Prominence in the Religion of Israel (New York: Peter Lang Publishing, 1998), 27-28.

10 See, for example, numerous contributions to Saul in Story and Tradition (ed. Carl S. Ehrlich and Marsha C. White; FAT 47; Tübingen: Mohr-Siebeck, 2006), especially Gary N. Knoppers, "Israel's First King and 'The Kingdom of YHWH in the Hands of the Sons of David': The Place of the Saulide Monarchy in the Chronicler's Historiography"; Avraham Faust, "Settlement Patterns"; Siegfried Kreuzer, "Saul—Not Always— 
ascribe definitively a name to the first king of Israel, mostly agree that given the location of Israel's emergence, a Benjaminite king is plausible. ${ }^{11}$ Some propose that Saul's selection was a compromise between Judah and Ephraim, since Benjamin had historic ties to both of Israel's strongest tribes and was a geographical "middle ground" between the two. ${ }^{12}$ The contrast in the text between Saul and David must be taken as quite significant for understanding the relationship between the tribes of Judah and Benjamin in Israel's historiography.

Benjamin appears to have played a key role as the border tribe between the Northern and Southern Kingdoms after the North's secession. ${ }^{13}$ The exact nature of that role, and the ties between the kingdoms called "Israel" and "Judah," are subject to much debate. The language of the oracles to Solomon and Jeroboam (1 Kgs 11:11-13; 11:29-39) leaves Benjamin's affiliation ambiguous: ten $^{14}$ tribes (vv. 31, 35) are torn from David's line, and only one is left for David (vv. 13, 32, 36). ${ }^{15}$ From the beginning of the period of divided monarchy the land of Benjamin was divided, torn between stronger ties to the north and southern kings attempting to create a buffer for their capitals. ${ }^{16}$ Even though portions of the land of Benjamin were part of the Northern Kingdom — notably Bethel ${ }^{17}$ most of Benjamin was part of the kingdom of Judah during the divided monarchy. ${ }^{18}$ After the fall of the Northern Kingdom to Assyria, Judah's annexation of Bethel and other Benjaminite territory may have partly been the

at War: A New Perspective on the Rise of Kingship in Israel"; and Yairah Amit, "The Delicate Balance in the Image of Saul and Its Place in the Deuteronomistic History."

11 Avraham Faust, "Settlement Patterns," 34. Levin, "Benjamin Conundrum," 223-241.

12 Klaus-Dietrich Schunck, Benjamin: Untersuchungen zur Entstehung und Geschichte eines israelitischen Stammes (BZAW 86; Berlin: Alfred Töpelmann, 1963), 171.

13 Schunck, Benjamin: Untersuchungen, 171-172.

14 The association of "ten tribes" is itself a stylization, since Simeon's region was contained within Judah's (Josh 19:9), and was apparently later absorbed into Judah: "The pattern of Judahite domination over and even absorption of Simeon is strongly suggested by the Deuteronomistic work" (Gary N. Knoppers, 1 Chronicles 1-9 [Anchor Bible Commentary; New York: Doubleday, 2004], 372). The Northern faction in Rehoboam's day would only have included nine tribes: Reuben, Gad, Dan, Asher, Naphtali, Zebulun, Issachar, Manasseh, and Ephraim — and possibly Benjamin, which is the very question at hand.

15 "I would suggest that rather than this being bad [sic] addition in an unskilfully told story, it is a purposeful reflection of the unclear status of the twelfth tribe, namely Benjamin, once again in an oracle attributed to a northern prophet" (Levin, "Benjamin Conundrum," 229n27).

16 Levin, "Benjamin Conundrum," 229.

17 Nadav Na'aman, "Saul, Benjamin and the Emergence of 'Biblical Israel' (Parts 1 \& 2)," ZAW 121 (2009): 338-342.

18 Na'aman, "Saul, Benjamin and the Emergence of 'Biblical Israel,"” 224. 
means by which Israelite/Northern traditions (e.g., exodus and judges traditions) came south to Judah. ${ }^{19}$

It is now widely acknowledged that the lands of the kingdom of Judah were continuously inhabited during the Babylonian period. ${ }^{20}$ Oded Lipschits has played a significant role in overturning "the myth of the empty land." The finding most relevant for this study is that the Benjaminite regions suffered little from the Babylonian invasion: "Archaeological finds from the Benjamin region.... as well as the finds from the northern Judean hill country, indicate continuous settlement in these parts in the sixth century BCE." ${ }^{21}$ Lipschits posits that the two most important Benjaminite sites under Babylonian rule were Mizpah, "an administrative centre" with some wealthy houses, storehouses and fortifications, and Gibeon, which "had great economic importance for the Benjamin region, and it might have served as an industrial centre for the winemaking activity in the region." 22

During the postexilic period, the regions of Judah and Benjamin appear to have constituted a single polity within the Persian Empire: Yehud Province. Interestingly, neither the loss of deportees under Babylonian rule nor the subsequent waves of returnees under early Persian rule appears to have had significant impact on the population of the Benjaminite region. However, starting late in the sixth century Benjamin appears to have experienced decline. ${ }^{23}$ Schunck suggests that the conflicts described in Ezra between the "people of the land" and the returning golah community may have resulted in the decline of some Benjaminite towns. ${ }^{24}$ This is where relations between Benjaminites and

19 Ernst A. Knauf, "Bethel: The Israelite Impact on Judean Language and Literature," in Judah and the Judeans in the Persian Period (ed. Oded Lipschits and Manfred Oeming; Winona Lake, IN: Eisenbrauns, 2006), 291-295; Davies, "The Trouble With Benjamin," 104-110.

20 Oded Lipschits, The Fall and Rise of Jerusalem: Judah under Babylonian Rule (Winona Lake, IN: Eisenbrauns, 2005); see also Hans M. Barstad, The Myth of the Empty Land: A Study in the History and Archaeology of Judah During the "Exilic" Period (Oslo: Scandinavian University Press, 1996).

21 Oded Lipschits, "The History of the Benjamin Region under Babylonian Rule," Tel Aviv 26 (1999): 164. Elsewhere, he notes: "From the foregoing no evidence emerges of destruction at the beginning of the sixth century, apart from the razing of parts of Tell el-Fûl. At all the excavated sites evidence of continuity of settlement exists between the seventh and sixth centuries, and of their existence throughout the time of Babylonian rule, until the last third of the sixth century" ("History of the Benjamin Region," 179).

22 Lipschits, "History of the Benjamin Region," 179. A cultic centre at Mizpah has also been suggested based on Jer 41:5 (Schunck, "Benjamin," 672-673).

23 Lipschits, "History of the Benjamin Region," 179.

24 "The archaeological record attests to the destruction of numerous Benjaminite towns (Bethel, Gibeon, Gibeah) in the first quarter of the 5th century BCE. The precise 
Judahites seem to have soured, and this seems to be the point at which the socalled Deuteronomistic History was reaching its final form.

It would be an oversimplification to suggest that all Benjaminites and Judahites were opponents during this period. The biblical texts, when properly interpreted as ideological portrayals of the Babylonian and Persian eras, indicate that at least some of the prosperous she'erit community of early Yehud were Benjaminites, who were influential in provincial government and came into conflict with the returnees. Benjaminites were among the returnees, and some she'erit Yehudians apparently joined with the golah community and associated with the Jerusalem cult (Ezr 6:21).

Though joined inseparably to those of Judahite ancestry and designated as "Jews" (יהודים), Benjaminites retained their separate tribal identity—as did the Levites. Benjaminite identity continued to be relevant to the self-understanding of many Jews in Palestine and the Diaspora well into the Hellenistic period. ${ }^{25}$

\section{MULTI-LEVELLED, TEXTUAL IDENTITIES}

The combination of archaeology and close readings of the biblical texts points to the early, ongoing and enduring significance of Benjaminite identity for the communities in which the biblical texts were produced and finalized. Having worked "forward" from the origins of Israel to see the significance of the tribe of Benjamin in history, we will now work "backward" from the Persian period: using these historical memories to reflect upon the narratives of Genesis 35-50.

Two assumptions undergird this analysis. First, most biblical texts, including Genesis, are composite works containing traditions that predate the final form of the text by many centuries. This is relatively uncontroversial; however, scholars have not reached any sort of consensus on precisely how and why the texts of the Pentateuch, for example, were shaped into their present form. ${ }^{26}$ My second presumption is not universally held, or perhaps not always applied by even those who hold it. I presume that the final form of the text is the product of some conscious intention by an individual or a group of individuals who presented the text in [something close to] its present form to the community for retention, reverence, and reproduction. These persons who shaped the biblical

significance of this is debated, although it seems to indicate some disturbances between the Judaean community in Jerusalem and Samaria to its north, possibly related to the political tensions described in Ezra 4" (Schunck, "Benjamin," 673).

25 Notable examples would be the figures of Esther and Mordecai in the book of Esther; and Saul of Tarsus/Paul the Apostle, who was proud of his Benjaminite heritage

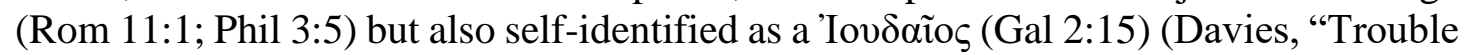
with Benjamin," 94-96).

26 I am well aware that there are multiple "final forms" of the Pentateuch, including the Samarian and Greek textual traditions. 
texts are variously called redactors, editors, documentarians, tradents, or authors. Though they are not "authors" in the modern sense, they may perhaps be thought of as "authorizers" or promulgators of the texts, who confirm and propagate the texts' authority in the community.

When addressing narratives, I prefer the term "storymakers," which is neutral with respect to the various compositional theories but encompasses the notion of intentionality. ${ }^{27}$ This is not to say that no compositional theory has any more merit than another. Rather, it is to acknowledge that 1) the text is composite; 2 ) in most cases we do not possess the pieces that preceded it, only the final form; ${ }^{28}$ and 3) someone put the text together and propagated it as it currently stands. Any compositional theory which purports to make sense of the pieces must account for the intentionality of the whole.

Given the apparent pro-Levi, pro-Judah agendas of the scribal communities that produced the biblical texts, the presence of Benjaminite and Northern Israelite material in the texts is remarkable in itself. Why did the communities that were called "Judah" - the Kingdom of Judah, and Yehud province under Babylonian and Persian rule - appropriate the identity and traditions of "Israel," while still maintaining identity of "Judah"? Fleming has written a fascinating treatment of this question; ${ }^{29}$ following his line of inquiry, I am interested in the legacy of Benjamin in "Judah's Bible." The concept of textual identities provides a fruitful way of conceptualizing this legacy.

The narrative texts are neither ideologically neutral, "pure" historiography-nor are they strictly propagandistic fiction. Competing tendencies are reflected in these texts: on the one hand, the ideologies and rhetorical goals of the authors (including the survival of the community), and on the other hand, the parameters created by community memory and tradition. The scribes were not free to simply fabricate. Rather, I suggest that they shaped tradition gradually, "along the margin." It is this balancing and gradual shaping that we find in Genesis 35-50.

What was the identity that the scribal communities hoped to maintain/shape/propagate, and how did they do it? Jewish communities throughout history have quite flexibly emphasized ethnicity, religion or nationality to varying degrees depending on the concerns of the community at

27 I have adopted this term from Gary E. Schnittjer, and I have not found it used in other biblical scholarship; see for example, "Individual versus Collective Retribution in the Chronicler's Ideology of Exile," Journal of Biblical and Theological Studies 4.1 (2019): 113-132 [125].

28 The book of Chronicles, which appears to be derived in part from some version of Samuel-Kings, is a notable and instructive exception.

29 Daniel E. Fleming, The Legacy of Israel in Judah's Bible: History, Politics, and the Reinscribing of Tradition (New York: Cambridge University Press, 2012). 
the time. ${ }^{30}$ What did it mean to be a Jew-more precisely, a Yehudi, a person connected to the province of Yehud? How did subordinate tribal identities within Israel operate, and how did Jewish/Israelite identity relate to imperial authority?

Following Jonker, we must take full account of the multidimensionality of self-categorizations in Persian Yehud. The history of this period reflects a process of self-identification not within a single socio-historical level but within multiple levels - imperial, regional, ethnic, and cultic. ${ }^{31}$ Reflecting on the evidence of this process in Chronicles, Jonker argues: "It is important to emphasise that these levels never functioned in isolation. The inhabitants of Yehud, and particularly the literati who were responsible for the writing of another historiography, the books of Chronicles, were exposed to all these contexts, and were active participants in all of them." 32

Given the complexity of the legacy of Israelite tribal identity, it makes perfect sense that the biblical texts edited and compiled during this period would have a blend of traditions from Northern, Benjaminite, Judahite and Levite communities. Yehud's imperial context placed a certain pressure on the scribal communities to retain the distinct voices of Israel's tribes within a work such as the Pentateuch, while being careful not to be so distinct as to undermine social cohesion.

\section{ISRAEL AND BENJAMIN THROUGH THE EYES OF THE STORYMAKERS}

Armed with this notion of "textual identities" within a text that is designed both to reflect and to shape the community, the reconstructed history of the complex relationship between the tribes of Israel (with Benjamin in the middle) opens up new lines of interpretation of Genesis 35-50. Such a reading leads to a greater focus on Judah as a transformed leader of Israel alongside Joseph, and a deeper appreciation of the conciliatory message of Genesis 35-50 in the face of complex Jewish identities in the Persian period.

30 See Shaye J. D. Cohen, The Beginnings of Jewishness: Boundaries, Varieties, Uncertainties (Berkeley, CA; University of California Press, 1999), especially 341-349.

31 Louis C. Jonker, "Engaging with Different Contexts: A Survey of the Various Levels of Identity Negotiation in Chronicles," in Texts, Contexts and Readings in Postexilic Literature (ed. Louis C. Jonker; Tübingen: Mohr-Siebeck, 2011), 63, 74, 91; and more recently, Jonker, Defining All-Israel in Chronicles: Multi-levelled Identity Negotiation in Late Persian-Period Yehud (FAT 106; Tübingen: Mohr Siebeck, 2016), especially chapter 3 .

32 Jonker, "Engaging with Different Contexts," 73-74. 


\section{$1 \quad$ Genesis 35}

In Genesis 35 we find the story of Benjamin's birth. Benjamin is Jacob's twelfth and youngest son, and the younger son of Rachel, the favoured wife, who dies giving birth to Benjamin.

The narrative of Benjamin's birth (Gen 35:16-20) immediately follows the second story of the changing of Jacob's name to "Israel" (35:9-15). Between Benjamin's birth and the story of the "generations of Jacob"- that is, the narratives focusing on Jacob's sons (37:2 onward) - we find the brief statement of Reuben's violation of his father's concubine (35:21-22), a list of Jacob's sons (35:23-26), the death and burial of Isaac (35:27-29), and the record of the descendants of Esau (36:1-43).

Interestingly, the placement of Benjamin's birth after Jacob's namechange means that, in the received form of the text, Benjamin is the only child born to "Israel." Earlier in Genesis, Isaac, the child of promise, is born to Abram only after his name is changed to Abraham (Gen 17). Later on, Joseph's sons, who will both be considered tribes of Israel by virtue of the birth right, are born to him (Gen 41:50-52) immediately after his name is changed by Pharaoh (Gen 41:45). These two narrative features - the isolation of Benjamin's birth, and the fact that he is the only child born to "Israel"- evoke Israel's origins as a nation in Benjaminite territory and the Benjaminite identity of Israel's first king.

The etymology of Benjamin's name and the tribal identification of the location of Rachel's grave point to tribal rivalry in later periods of Israel's history. Like his father, Benjamin experiences a name-change after birth, having been named "Ben-oni" by his mother but "Benjamin" by his father. "Benjamin" can be understood either as "son of the south," or as "son of the right hand." In the context of the emerging Israelite monarchy, the etymology preferred by Benjaminites who perceived closer ties to the Josephite tribes to their north would have been "son(s) of the south." As Fleming observes, "If Benjamin is really 'southern' in local terms...it is from an Ephraimite point of view." ${ }^{33}$ By contrast, the "son(s) of the right hand" etymology is the basis for numerous instances of wordplay in the Hebrew Bible concerning left-handed (lit.

33 Fleming, Legacy of Israel in Judah's Bible, 147. Interestingly, the Samaritan Pentateuch renders Benjamin's name as בנימים, "son of days"; Tsedaka suggests, "He was only one day old when his mother died. His father wished him a long life by calling him a son of days." Benyamim Tsedaka, ed. and trans., The Israelite Samaritan Version of the Torah: First English Translation Compared with the Masoretic Version (Grand Rapids: Eerdmans, 2013), 84. It appears that the Northern-oriented "son of the south" etymology had long fallen out of favor even among Samarians by the Persian and Hellenistic periods. 
"right-hand-hindered" אטר יד־ימין) or ambidextrous Benjaminites who are contrasted with Judahites (Judg. 3:15; 20:16; 1 Chr 12:2). ${ }^{34}$

Blenkinsopp observes that Genesis 35:19 offers a gloss for the location of Rachel's grave as near "Ephrath - that is, Bethlehem," placing this revered site within Judahite borders. However, 1 Samuel 10:2 explicitly places Rachel's grave in Benjaminite territory, and Jeremiah 31:15 seems to confirm this Benjaminite association by placing Rachel's "weeping voice" from the grave in Ramah, also a Benjaminite site. ${ }^{35}$

The preference in Genesis 35 for the "right hand" etymology over the "south" etymology of "Benjamin," and the co-opting of Rachel's gravesite, are evidence of Judahite influence on the narrative. However, contra Blenkinsopp, it is not necessary to read this as the result of Benjaminite-Judahite rivalry in the early Persian period. ${ }^{36}$ Given the tug-of-war over Benjamin between Judah and Joseph that I believe we see in Genesis 42-45, these moves could be interpreted as Judahite attempts at closer ties to Benjamin rather than domination of Benjamin.

\section{Reuben Eclipsed by Judah and Joseph}

On the heels of Benjamin's birth is the reference to Reuben's sin with Bilhah, Jacob's concubine. Though the reference is brief and no direct consequence is mentioned ("Israel heard of it"), through the rest of Genesis Reuben never seems to recover from this mistake, leading up to his being passed over for the blessing of the firstborn (Gen 49:3-4; cf. 49:10).

In later Israel's story, we see Reuben eclipsed as firstborn in Israel by Judah (Jdg 1:2; 20:18). Reuben is also eclipsed as a Transjordan tribe by halfManasseh (i.e., Gilead): Gileadites have two judges (Jair and Jephthah) and thirteen references in Samuel and Kings_-whereas Reuben is only referenced twice in all of Judges, Samuel and Kings (Jdg 5:15-16; 2 Kgs 10:33).

Returning to the Genesis narrative, Reuben is similarly eclipsed at every turn by Joseph or Judah. Reuben's plan to rescue Joseph from the other brothers is thwarted by Judah (37:21-30). Later, his plan to rescue Simeon from Joseph

\footnotetext{
34 Giffone, “'Special Forces,"” passim.

35 Joseph Blenkinsopp, "Benjamin Traditions Read in the Early Persian Period," in Judah and the Judeans in the Persian Period (ed. Oded Lipschits and Manfred Oeming; Winona Lake, IN: Eisenbrauns, 2006), 630-631.

36 "In view of the persistence or revival of a distinctly Benjaminite identity in the Neo-Babylonian Period, together with the indications of Judean-Benjaminite hostility referred to above, we should allow for the possibility that the takeover of the grave tradition of the great matriarch was one aspect of the process by which JudeanJerusalemite hegemony was revalidated during the first century of Persian rule" (Blenkinsopp, "Benjamin Traditions," 633).
} 
is rejected; Israel entrusts Benjamin to Judah, not Reuben (42:37-43:14). ${ }^{37}$ When the brothers plead for Benjamin before Joseph, it is Judah, not Reuben, who speaks boldly (44:14-34) - in fact, the text refers to the ten as "Judah and his brothers" (44:14). Judah, not Reuben, leads the way when Jacob migrates to Egypt (46:28).

Reuben's fall from grace and subsequent haplessness within the story underscores the successes of his younger brothers who split his inheritance: the blessing of the firstborn (Judah; see 49:8-12) and the double-portion birth right (Joseph; see 48:8-20). As we will see, these two brothers struggle for primacy in the story and control over Benjamin - while Reuben, like the tribe that would bear his name, is left in the dust.

\section{Development of Judah's Character}

Judah is among the most significant of the Israelite tribes in the Hebrew Bible: the tribe of King David and the Southern kings, and one of the primary constituent tribes of Yehud province that survives the exile. The Hebrew Bible in its final form bears the mark of pro-Judah editors and redactors.

The role of the character Judah in the so-called "Joseph Novella" has sometimes been underappreciated. ${ }^{38}$ Joseph is clearly a focus within the narrative, which unfolds according to his dreams (Gen 37:5-11). But even as Joseph is brought on a journey of suffering and forgiveness, Judah is transformed from a man who would sell his own brother into slavery (or even kill his brother) into a man who would risk his life to save a brother: first Simeon, a full brother, and then Benjamin, a half-brother.

Judah's role in the narrative has been underestimated in part because source-critical approaches have recognized Genesis 38 as an addition into a Northern Israelite tradition. For example, Brueggemann writes: "This peculiar chapter stands alone, without connection to its context. It is isolated in every way and is most enigmatic. It does not seem to belong with any of the identified sources of ancestral tradition." 39

37 Reuben's brilliant plan: "If your two sons [of your favoured wife] are killed, then kill my two sons!"

38 Iain Provan, Discovering Genesis: Content, Interpretation, Reception (Grand Rapids: Eerdmans, 2015), 185.

39 Walter Brueggemann, Genesis (Interpretation Series; Atlanta: John Knox Press, 1982), 307. Speiser asserts, "The narrative is a completely independent unit. It has no connection with the drama of Joseph, which it interrupts at the conclusion of Act I"; Ephraim A. Speiser, Genesis: Introduction, Translation and Notes (Anchor Bible; Garden City, NY: Doubleday, 1964), 299. See also Claus Westermann, Genesis (trans. David E. Green; London: T\&T Clark, 1987), 268. 
Yet numerous narrative and linguistic similarities connect Genesis 38 to the preceding and succeeding chapters. ${ }^{40}$ In chapter 37 , Judah and his brothers kill a goat, dip Joseph's cloak in its blood, and then knowingly ask Jacob to "recognize" (הכר־נא) whose cloak it is. In chapter 38, Tamar accepts Judah's signet ring, cords and staff as pledge for a goat, and then knowingly asks Judah to "recognize" (הכר־נא) the items as belonging to the man who has impregnated her. ${ }^{41}$

This encounter with Tamar may be considered a turning point in Judah's life; he tricked his trickster father, but now his daughter-in-law has turned the tables on him. Later, when a close family member-Joseph-disguises himself so that Judah cannot "recognize" him (42:8 לא הכרהו), Judah fulfils his obligation by protecting the more vulnerable family member-Benjamin.

From a redactional standpoint, Genesis 38 does in fact appear to be a later insertion into the story. ${ }^{42}$ This sort of addition and shaping of a Northern-oriented narrative in a pro-Judah direction is just the sort of activity that, I would argue, may be observed in Judges and Samuel. ${ }^{43}$ However, this editorial activity is not

40 Schnittjer observes at least five connections between Gen 38 and the surrounding narratives; see The Torah Story, 163-164. Hamilton, though acknowledging Gen 38 as a later insertion into the Joseph narrative, likewise observes literary connections: Victor P. Hamilton, The Book of Genesis: Chapters 18-50 (NICOT; Grand Rapids: Eerdmans, 1995), 431.

41 Gordon Wenham, Genesis 16-50 (WBC; Dallas: Word Books, 1994), 364. Schnittjer observes that Joseph is also identified by his cloak when falsely accused by Potiphar's wife (39:12-18), though the terms are not exactly the same (Torah Story, 164-165).

42 See the discourse analyses of Robert E. Longacre, Joseph-A Story of Divine Providence: A Text and Text-linguistic Analysis of Genesis 37 and 39-48 (Winona Lake: Eisenbrauns, 1989), 26; and Roy L. Heller, Narrative Structure and Discourse Constellations: An Analysis of Clause Function in Biblical Hebrew Prose (HSS 55; Winona Lake: Eisenbrauns, 2004), 39-40.

Redford notes the chronological difficulties caused by placing Genesis 38 between chapters 37 and 39 - which the author of Jubilees may have tried to smooth by placing the Judah-Tamar story between the ten brothers' two trips to Egypt (i.e., between Genesis 42 and 43); see Donald B. Redford, A Study of the Biblical Story of Joseph (Genesis 37-50) (VTSupp 20; Leiden: Brill, 1970), 17-18.

43 Regarding Judges, see Robert G. Boling, Judges: A New Translation with Notes and Commentary (Anchor Bible; Garden City, NY: Doubleday, 1975), 29-38; Trent C. Butler, Judges (WBC; Nashville: Thomas Nelson, 2009), xlix; Barry G. Webb, The Book of Judges (NICOT; Grand Rapids: Eerdmans, 2012), 20-32.

Regarding Samuel, see the discussion in Marsha C. White, "Saul and Jonathan in 1 Samuel 1 and 14," in Saul in Story and Tradition, 120-124; Gregory Mobley, "Glimpses of the Heroic Saul," in Saul in Story and Tradition, 80. It is usually argued that 1 Sam 9-14 formed the core of this Saul narrative. White points out the connections 
haphazard ${ }^{44}$ : the larger narrative of Jacob's sons does indeed cohere as a whole. The additions do not whitewash Judah's character, nor do they completely obscure the positive role of Joseph.

\section{Benjamin: Silent and Passive between Judah and Joseph}

The character of Benjamin in Genesis $35-50$ is entirely silent and passive-and yet he becomes a significant object not only to his father but to his brothers around him. ${ }^{45}$

The Benjaminite territories, as we have seen, were the heart of the emerging and united Israel. Later, Benjamin was at the centre of a tug-of-war between Judah and the Northern coalition led by Manasseh and Ephraim. This political question is embedded Genesis 42-45: With whom does Benjamin belong?

Genesis 42 begins with Jacob sending the ten brothers to Egypt to purchase grain; he keeps Benjamin behind because he has lost Joseph and is not willing to risk Rachel's other son. As the conflict unfolds, Joseph schemes to have Benjamin brought to himself-his motives are not clear until the end of the story. Jacob initially refuses to entrust Benjamin to the nine brothers; Reuben in particular asks to take Benjamin into his charge and is rebuffed (42:37-38). Only when the grain runs out does Jacob entrust Benjamin to Judah (43:8-9).

Genesis 42-45 presents a comparison between Judah and Joseph, and the measure of fraternal loyalty is each brother's treatment of Benjamin. When Benjamin finally comes with the nine brothers, Joseph gives Benjamin a feast portion from his own table - a portion five times larger than the portions given to the other brothers (43:34). This is neatly paralleled by Joseph's gifts to his brothers after he reveals his identity to them: each of the older brothers receives a change of clothes, but Benjamin receives five changes of clothes and 300 pieces

between 1 Sam 1-2 and Saul-Jonathan, so perhaps some earlier version of 1 Sam 1-14 formed an original narrative of Saul's anointing prophet, Saul's rise, and Saul's success.

44 "Whoever put the story as we have it in its present position, must have been guided by what seemed to him a sound literary principle: either a thematic or idiomatic connection or association must be present between the story of the sale of Joseph into bondage and the account of Judah's encounter with Tamar. It seems to me that the approach has merit. In no way do I mean to imply that the Judah-Tamar unit could not have been originally an independent tale for purposes completely of its own. Nor need we either reject or adopt any of the documentary-source theories recommended by different Bible critics. One day, however, the Judah-Tamar story as we have it was united with our present Joseph story. That union, like discrimination of hypothetically independent sources, also deserves attention." Judah Goldin, "The Youngest Son or Where Does Genesis 38 Belong," JBL 96.1 (1977): 29.

45 Brueggemann refers to Benjamin as a "pawn" and "the focus of the brothers, of the father and of Joseph" (Genesis, 342). 
of silver (45:22). Yet in the middle of the story, Joseph endangers Benjamin's life by placing his divination cup in Benjamin's grain sack $(44: 1-2,5)$.

Judah's actions toward Benjamin are also crucial. Judah "gives himself as

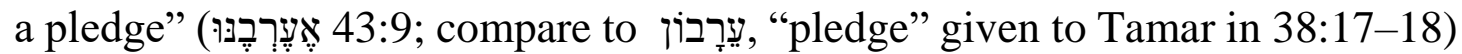
to Jacob for Benjamin's safety. He fulfils this promise (44:32) by offering himself as a slave in Benjamin's place (44:33). However, in the middle of the story Judah along with the brothers (he is not named specifically) makes an ignorant vow that endangers Benjamin's life. ${ }^{46}$

In the end, the focus of Genesis $42-45$ is not really a "contest" between Judah and Joseph, but reconciliation between brothers. The key moments in the story that lead to that resolution all relate to Benjamin. Both brothers speak words that endanger Benjamin's life, and both brothers offer Benjamin protection. While Joseph's choice to forgive remains the dominant thread in the narrative, his choice is a response to Judah's courage in protecting Benjamin. Judah is instrumental in reuniting Joseph with Benjamin and later with Jacob as well (46:28).

\section{E CONCLUSION: EMBEDDED TRIBAL STRUGGLES}

In conclusion, I offer several observations on the embedded textual identities of Israel's tribes in Genesis 35-50.

First, there are enough parallels to later Israelite history to justify seeing intertribal relations in the identities embedded within the narrative. While the transmission history of these traditions remains opaque, we may affirm with reasonable confidence that the old stories were shaped so as to ensure their continuing relevance for the communities in which they were finalized.

Second, Genesis 35-50 contains various layers of "contribution." These layers may be seen in the peculiar interests of certain passages in tribal ancestors or locations. Far from being edited haphazardly, we have seen that the tribal history embedded within the text actually lends coherence by explaining the inclusion of such traditions as Genesis 38 in the final form.

Third, like each of the books of the Deuteronomistic History, Genesis 3550 appears to contain layers of Northern Israelite/Josephite, Benjaminite, and Judahite traditions. The Judahite contribution, which is likely to have been the

46 Schnittjer (Torah Story, 167) compares the brothers' vow to Jacob's statement to Laban in Gen 31:32 that whoever stole Laban's household idols would die. Both vows are spoken in indignation but ignorance; both vows concern stolen property related to pagan religious practice (Laban's idols; Joseph's divination cup). Schnittjer also suggests based on temporal markers in the text that Rachel could have been pregnant with Benjamin in Genesis 31, meaning that his life is endangered in both instances. 
final layer, nevertheless retains a great deal of positive material about Joseph and Benjamin.

Finally, the message to the tribes embedded in Genesis 35-50 is an "All Israel," conciliatory message. The book of Chronicles and prophetic texts such as Ezekiel 37:15-28, Ezekiel 48, Jeremiah 31:31-34 and Isaiah 11 envision a reunification of Northern Israel and Judah under a Judahite ruler-perhaps not an ideal shared by the Josephite tribes and Benjaminites. Nevertheless, we see in these texts - as in Genesis 35-50 - an attempt within "Judah's Bible" to pull both Benjamin and Joseph toward Judah. Even though the Northern tribal identities persisted beyond the destruction of the Northern Kingdom by the Assyrians in the eighth century, ${ }^{47}$ Benjamin was the "other" constituent tribe of "Israel" in the Babylonian and Persian periods beside the royal tribe of Judah and the priestly tribe of Levi. Therefore, whatever inclusive visions of Israelite reunification there may be in the prophetic texts, we should understand these inclusive messages as directed toward Benjaminites in practice.

The well-known and beloved story of Joseph and his brothers in the last third of Genesis is indeed a story about forgiveness and reconciliation. It offers us a window into Judahite perceptions of Judah-Benjamin relations. Benjaminites seem to have always perceived close ethnic ties to their Josephite neighbours to the north. But fate (or Providence) determined that Benjamin would come under the wing of Judah's protection to the south. This is precisely how the post-exilic scribes who shaped the Hebrew scripture envisioned these two tribes: thrown together by circumstance, and forming an enduring union that proved vital to the survival of "Israel" and its traditions.

\section{BIBLIOGRAPHY}

Amit, Yairah. "The Delicate Balance in the Image of Saul and Its Place in the Deuteronomistic History." Pages 71-79 in Saul in Story and Tradition. Edited by

Carl S. Ehrlich and Marsha C. White. FAT 47. Tübingen: Mohr-Siebeck, 2006.

Barstad, Hans M. The Myth of the Empty Land: A Study in the History and Archaeology of Judah during the "Exilic" Period. Oslo: Scandinavian University Press, 1996.

Blenkinsopp, Joseph. "Benjamin Traditions Read in the Early Persian Period." Pages 629-645 in Judah and the Judeans in the Persian Period. Edited by Oded Lipschits and Manfred Oeming. Winona Lake, IN: Eisenbrauns, 2006.

Boling, Robert G. Judges: A New Translation with Notes and Commentary. Anchor Bible. Garden City, NY: Doubleday, 1975.

Brueggemann, Walter. Genesis: A Commentary for Teaching and Preaching. Interpretation series. Atlanta: John Knox Press, 1982.

Butler, Trent C. Judges. WBC. Nashville: Thomas Nelson, 2009.

Cohen, Shaye J. D. The Beginnings of Jewishness: Boundaries, Varieties, Uncertainties. Berkeley, CA: University of California Press, 1999.

47 As evidenced by, for example, the Josephite returnees from Babylon (1 Chr 9:3) and the identification of the prophetess Anna as "Asherite" (Lk 2:36). 
Davies, Philip R. "The Trouble with Benjamin." Pages 93-111 in Reflection and Refraction: Studies in Biblical Historiography in Honour of A. Graeme Auld. Edited by Robert Rezetko et al. VTSup 113. Leiden: Brill, 2007.

Faust, Avraham. "Settlement Patterns and State Formation in Southern Samaria and the Archaeology of (a) Saul." Pages 14-38 in Saul in Story and Tradition. Edited by Carl S. Ehrlich and Marsha C. White. FAT 47. Tübingen: Mohr-Siebeck, 2006.

Fleming, Daniel E. The Legacy of Israel in Judah's Bible: History, Politics, and the Reinscribing of Tradition. New York: Cambridge University Press, 2012. https://doi.org/10.1017/CBO9781139163033.

Giffone, Benjamin D. 'Sit at My Right Hand': The Chronicler's Portrait of the Tribe of Benjamin in the Social Context of Yehud. LHBOTS 628. New York: Bloomsbury T\&T Clark, 2016.

Giffone, Benjamin D. "Special Forces': A Stereotype of Benjaminite Soldiers in the Deuteronomistic History and Chronicles." SJOT 30.1 (2016): 16-29. https:// doi.org/10.1080/09018328.2016.1122287.

Glatt-Gilad, David A. "Chronicles as Consensus Literature.” Pages 67-75 in What Was Authoritative for Chronicles? Edited by Ehud Ben Zvi and Diana Edelman. Winona Lake, IN: Eisenbrauns, 2011.

Goldin, Judah. "The Youngest Son or Where Does Genesis 38 Belong." JBL 96.1 (1977): 27-44. https://doi.org/10.2307/3265325.

Hamilton, Victor P. The Book of Genesis: Chapters 18-50. NICOT. Grand Rapids: Eerdmans, 1995.

Heller, Roy L. Narrative Structure and Discourse Constellations: An Analysis of Clause Function in Biblical Hebrew Prose. HSS 55. Winona Lake: Eisenbrauns, 2004.

Jonker, Louis C. Defining All-Israel in Chronicles: Multi-levelled Identity Negotiation in Late Persian-Period Yehud. FAT 106. Tübingen: Mohr Siebeck, 2016. https:// doi.org/10.1628/978-3-16-154596-2.

Jonker, Louis C. "Engaging with Different Contexts: A Survey of the Various Levels of Identity Negotiation in Chronicles." Pages 63-93 in Texts, Contexts and Readings in Postexilic Literature. Edited by Louis C. Jonker. FAT 53. Tübingen: Mohr-Siebeck, 2011. https://doi.org/10.1628/978-3-16-151852-2.

Jonker, Louis C. "Of Jebus, Jerusalem and Benjamin: The Chronicler's Sondergut in 1 Chronicles 21 Against the Background of the Late Persian Era in Yehud." Pages 81-102 in Chronicling the Chronicler: The Book of Chronicles and Early Second Temple Historiography. Edited by Tyler F. Williams and Paul S. Evans. Winona Lake, IN: Eisenbrauns, 2013.

Knauf, Ernst A. "Bethel: The Israelite Impact on Judean Language and Literature." Pages 291-349 in Judah and the Judeans in the Persian Period. Edited by Oded Lipschits and Manfred Oeming. Winona Lake, IN: Eisenbrauns, 2006.

Knoppers, Gary N. "Israel's First King and 'The Kingdom of YHWH in the Hands of the Sons of David': The Place of the Saulide Monarchy in the Chronicler's Historiography." Pages 187-213 in Saul in Story and Tradition. Edited by Carl S. Ehrlich and Marsha C. White. FAT 47. Tübingen: Mohr-Siebeck, 2006.

Knoppers, Gary N. 1 Chronicles: A New Translation with Introduction and Commentary. 2 vols. Anchor Bible. New York: Doubleday, 2004.

Knoppers, Gary N. and Bernard Levinson, eds. The Pentateuch as Torah: New Models for Understanding Its Promulgation and Acceptance. Winona Lake, IN: Eisenbrauns, 2007. 
Kreuzer, Siegfried. "Saul-Not Always - at War: A New Perspective on the Rise of Kingship in Israel." Pages 39-58 in Saul in Story and Tradition. Edited by Carl S. Ehrlich and Marsha C. White. FAT 47. Tübingen: Mohr-Siebeck, 2006.

Langston, Scott M. Cultic Sites in the Tribe of Benjamin: Benjaminite Prominence in the Religion of Israel. New York: Peter Lang Publishing, 1998.

Levin, Yigal. "Joseph, Judah and the 'Benjamin Conundrum." ZAW 116 (2004): 223 241. https://doi.org/10.1515/zatw.2004.011.

Lipschits, Oded. "The History of the Benjamin Region under Babylonian Rule." Tel Aviv 26 (1999): 155-90.

Lipschits, Oded. The Fall and Rise of Jerusalem: Judah under Babylonian Rule. Winona Lake, IN: Eisenbrauns, 2005. https://doi.org/10.1179/tav.1999.1999.2.155.

Longacre, Robert E. Joseph-A Story of Divine Providence: A Text and Text-linguistic Analysis of Genesis 37 and 39-48. Winona Lake: Eisenbrauns, 1989.

Mobley, Gregory. "Glimpses of the Heroic Saul." Pages 80-87 in Saul in Story and Tradition. Edited by Carl S. Ehrlich and Marsha C. White. FAT 47. Tübingen: Mohr-Siebeck, 2006.

Na'aman, Nadav. "Saul, Benjamin and the emergence of 'Biblical Israel' (Parts 1 \& 2)." ZAW 121 (2009): 211-224, 335-349. https://doi.org/10.1515/ZAW.2009.014.

Provan, Iain. Discovering Genesis: Content, Interpretation, Reception. Grand Rapids: Eerdmans, 2015.

Redford, Donald B. A Study of the Biblical Story of Joseph (Genesis 37-50). VTSupp 20. Leiden: Brill, 1970.

Schnittjer, Gary E. The Torah Story: An Apprenticeship on the Pentateuch. Grand Rapids: Zondervan, 2006.

Schunck, Klaus-Dietrich. "Benjamin.” Translated by Phillip R. Callaway. Pages 671673 in Anchor Bible Dictionary, vol. 1. Edited by David Noel Freedman. New York: Doubleday Publishing, 1992.

Schunck, Klaus-Dietrich. Benjamin: Untersuchungen zur Entstehung und Geschichte eines israelitischen Stammes. BZAW 86. Berlin: Alfred Töpelmann, 1963.

Speiser, Ephraim A. Genesis: Introduction, Translation and Notes. Anchor Bible. Garden City, NY: Doubleday, 1964.

Tsedaka, Benyamim, editor and translator, with Sharon Sullivan. The Israelite Samaritan Version of the Torah: First English Translation Compared with the Masoretic Version. Grand Rapids: Eerdmans, 2013.

Webb, Barry G. The Book of Judges. NICOT. Grand Rapids: Eerdmans, 2012.

Wenham, Gordon. Genesis 16-50. WBC. Dallas: Word Books, 1994.

Westermann, Claus. Genesis. Translated by David E. Green. London: T\&T Clark, 1987.

White, Marsha C. "Saul and Jonathan in 1 Samuel 1 and 14." Pages 119-138 in Saul in Story and Tradition. Edited by Carl S. Ehrlich and Marsha C. White. FAT 47. Tübingen: Mohr-Siebeck, 2006.

Dr Benjamin D. Giffone, LCC International University, Centre for Faith and Human Flourishing, Kretingos 36, Klaipėda, Lietuva, LT-92307; Stellenbosch University, Department of Old and New Testament, Research Associate. Email bgiffone@1cc.lt. ORCID: http://orcid.org/0000-0003-0907-6514. 